IJLRES - International Journal on Language, Research and Education Studies

ISSN: 2580-6777 (p); 2580-6785 (e)

DOI: $10.30575 / 2017 /$ IJLRES-2018091208

Vol. 2, No. 3, 2018

Page: $391-407$

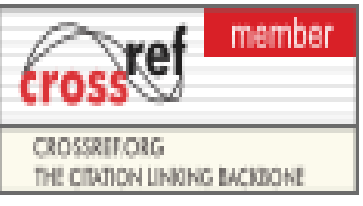

\title{
THE EFFECT OF SYNTAGMATIC AND PARADIGMATIC RELATIONSHIPS ON LEARNING GRAMMAR AMONG IRANIAN PRE-INTERMEDIATE EFL LEARNERS
}

\author{
Ehsan Namaziandost \\ PhD Student, Department of English, Faculty of Humanities, Shahrekord Branch, \\ Islamic Azad University, Shahrekord, Iran \\ e.namazi75@yahoo.com \\ Fariba Rahimi Esfahani \\ Assistant Professor, Department of English, Faculty of Humanities, Shahrekord \\ Branch, Islamic Azad University, Shahrekord, Iran \\ rahimi_fariba@yahoo.com \\ Akbar Khajehpour \\ Department of literature, Baghemalek Branch, Payame Noor University, Baghemalek, \\ Iran \\ khajehpour63@gmail.com
}

\begin{abstract}
The purpose of the present study was to explore the effects of using syntagmatic and paradigmatic relationships on learning grammar among Iranian pre-intermediate EFL learners. To fulfill the objectives of the study a Homogeneity test (Oxford Quick Placement Test) was administered among 70 students at the pre-intermediate level of a private language Institute and finally 40 participants were selected. Then, they were randomly divided into two subgroups, namely control and experimental groups. Before starting the treatment, a validated teacher-made grammar test was administered to students as pre-test to assess the participants' knowledge of grammar at the beginning of the course. Then, the experimental group received the treatment, which was teaching grammar through using syntagmatic and paradigmatic relations while the control group was taught using traditional methods of teaching. After 20 sessions of treatment, the two groups were administered the same teacher-made grammar test as post-test. Data were analyzed by Paired and Independent Samples t-test. The findings showed that the experimental group significantly performed better than the control group. Generally, the experimental groups outperformed the control groups. The results suggest that syntagmatic and paradigmatic relations can be used in English classes to develop listening grammar ability among Iranian EFL learners.
\end{abstract}

Keywords: Grammar, Syntagma, Paradigma

\section{INTRODUCTION}

At the core of arguments on issues, such as the role of grammar in educational programs (Richards \& Rodgers, 2001) and techniques for teaching language skills and sub-skills more efficiently are differing viewpoints on the value of grammar for the 


\section{The Effect of Syntagmatic and Paradigmatic Relationships on Learning Grammar \\ Among Iranian Pre-Intermediate EFL Learners \\ DOI: 10.30575/2017/IJLRES-2018091208}

language learner and opposing views of what instructive advantages learning grammar may or may not accrue (Myhill \& Watson, 2014).

Grammar is considered as one of the most important aspects of English language that students want to master in order to ensure success in learning L2, especially in writing. It seems that with high grammar knowledge, English learners tend to make greater progress in other areas of language learning. Grammar should be an active process to involve learners to use it in real contexts. Grammar is being taught in Iranian context explicitly most of the time, but this method of teaching is not effective anymore. Students always have a struggle with grammar and their teachers have grown frustrated over mistakes in their writing and speaking.

Moreover, the ability to utilize grammar accurately, meaningfully and properly is required for English student to convey both in oral and written way. What is to compose and talk must be founded on correct grammar, so that the message communicated can be found out. Consequently, it can be derived that mastery of grammar is a fundamental segment of second language acquisition, so it is vital for teachers and researchers to comprehend the necessity of grammar in picking up the information of language. Rutherford cited in Larsen- Freeman (1991) asserted that the necessary components of any language teaching program are grammatical patterns. As indicated by Richards and Renandya (2002) grammar is not the thing to be ignored in language teaching. As a result without extensive information of grammar, learners' learning improvement will be restricted.

Now the question, which is important to consider, is: what is the suitable method for teaching grammatical points to second and foreign language learners? Here the researcher prefers Syntagmatic and paradigmatic relations. In fact, the signs in the language framework are identified with each other in two courses: there are rules for their mix, and there are complexities and similitudes between them. These two measurements (mix and difference/comparability) are generally represented diagrammatically as two axes, the syntagmatic and paradigmatic.

\begin{tabular}{|l|l|l|l|l|l|l|}
\hline \multicolumn{1}{|c|}{ Relationships } & \multicolumn{9}{|c|}{ c---- Syntagmatic ------> } \\
\hline A I & A & dog & Fell & in & this & chair \\
\hline Paradigmatic & The & cat & Sat & on & the & mat \\
\hline
\end{tabular}




\section{The Effect of Syntagmatic and Paradigmatic Relationships on Learning Grammar \\ Among Iranian Pre-Intermediate EFL Learners \\ DOI: $10.30575 / 2017 /$ IJLRES-2018091208}

\begin{tabular}{l|l|l|l|l|l|} 
I That & man
\end{tabular}

Syntagmatic relations are quick straight relations between units in a segmental succession. The mix of two words or word-bunches one of which is changed by alternate structures a unit which is alluded to as a syntagmatic (Seker, 2013). There are four fundamental sorts of notional syntagmas: predicative (the blend of a subject and a predicate), objective (-/ - a verb and its question), attributive (a thing and trait), verbmodifying (a changed notional word, for example, a verb, descriptive word, or intensifier, with its verb-modifying modifier). The other kind of relations, restricted to syntagmatic and called "paradigmatic», are, for example, exist between components of the framework outside the strings where they co-happen. Dissimilar to syntagmatic relations, paradigmatic relations can't be specifically seen in expressions that is the reason they are alluded to as relations «in absentia» (Pustejovsky, 2000).

Paradigmatic relations exist together with syntagmatic relations such that some kind of syntagmatic association is important for the acknowledgment of any paradigmatic arrangement. This is particularly clear in a traditional linguistic worldview which shows a profitable arrangement of structures each comprising of a syntagmatic association of two components: one normal for the entire of the arrangement, the other particular for each individual shape in the arrangement (Haruki, 2006).

Regarding the mentioned points, the present study aims to seek the effect of syntagmatic and paradigmatic relationships on learning grammar among Iranian preintermediate EFL learners. If we want to understand better how to learn grammar in English, syntagmatic and paradigmatic relations help. Using this technique has a great importance in teaching process. However, the intrinsic usefulness of the various types of language learning strategies also depends on how they have been used by the teachers.

\section{REVIEW OF THE LITERATURE}

\section{Grammar}

The history of grammar analysis goes back to the ancient Greeks, who transformed it from the art of writing and recognizing letters into a science of rules that govern the production of texts. Both the Greeks and Romans, who adopted the Greek analysis for Latin, used grammar to teach people how to use languages, which were then employed 


\section{The Effect of Syntagmatic and Paradigmatic Relationships on Learning Grammar Among Iranian Pre-Intermediate EFL Learners DOI: $10.30575 / 2017 /$ IJLRES-2018091208}

in many fields, such as politics, philosophy, and religion (Celce-Murcia, 1991; De Mauro, 2009). Then the investigation of Greek and Latin sentence structures spread on account of the innovation of printing, and numerous formal studies on language created. On the other hand, during the 17th century, there was an increment in the utilization of vernaculars and the investigation of languages concentrated on their utilization and not on their formal examination, as there was a strong interest in learning the languages of other countries. In the eighteenth century the distinction in the middle of implicit and explicit grammar developed, and in the nineteenth century, the formal investigation of traditional dialects assumed control once more. From that minute, a persistent swing between the significance of grammar utilization and formal examination has portrayed the historical backdrop of grammar (Celce-Murcia, 1991). As regards the present days, the concept of grammar is polysemous, as it can show the interior working of the phonetic framework; learners' unequivocal information of the language, which is portrayed by sentence structures; and the metalinguistic model used to depict that express learning (Giunchi, 1990).

Grammar s vital to the instructing and learning of dialects. It illuminates the sorts of words and word bunches that make up sentences in any language and makes it feasible for us to discuss language. In fact, grammar is the way in which sentences are organized and the language is designed, so while concentrating on right punctuation may be a touch exhausting, it truly is justified regardless of the time and exertion. If we don't know the rules of grammar, then we will never have the capacity to convey obviously and successfully in English language. People associate grammar with errors and accuracy. With the utilization of erroneous language structure sentences can get to be meaningless and their message is unclear (Soleimani \& Khandan, 2013). So, thinking about grammar helps us comprehend what makes sentences and sections clear and intriguing and exact. Grammar and language structure can be a piece of writing talks, when we and our students nearly read the sentences in verse and stories. Also, thinking about sentence structure means discovering that all dialects and all languages take after grammatical patterns.

Using appropriate language structure, i.e., grammar is considered as an essential to have the capacity to finish sentences in trading information and data. According to Swan (2005) grammar is the rules that show how words are joined, organized or changed 


\section{The Effect of Syntagmatic and Paradigmatic Relationships on Learning Grammar \\ Among Iranian Pre-Intermediate EFL Learners \\ DOI: 10.30575/2017/IJLRES-2018091208}

to demonstrate certain sorts of meaning. Grammar is simply the path in which words change and gathering together to make sentences. It is argued that a basic knowledge of grammar underlies the ability to utilize the language, to express meaning. The right spelling or words and sentence structure are utilized to increase errors. Moreover, grammar is a theory of language, of how language is set up together and how it functions. More particularly, "grammar is the study of wording. Wordings are characterized such that they are able to explain meaning" (Gerot \& Wignel, p. 1994). Ur (1991) defined Grammar as "the way language manipulates and combines words (or bits of words) in order to form longer units of meaning" (p.4). This definition is very close to the common understanding of grammar.

By learning grammar rules, learners can maintain a strategic distance from language fossilization and enhance their execution, among other related points of interest. In addition, knowing language structure principles make autonomous learners who can control their learning procedure when they are out of school and when time contains the learning knowledge to the classroom only.

Crystal (2004) states that grammar is the base of our capability to express ourselves. The more we know how it works, the more we can monitor the meaning and effectiveness of the way we and others use language. Furthermore, Maugham (1938) holds that it is vital to learn grammar, and it is ideal to compose grammatically than not, but it is well to recall that grammar is basic speech formulated.

To sum up, grammar refers to composed sentence language structure. It includes the investigation of syntax (word order), clause and phrase structure, and the classification of parts of speech (e.g. noun, verb, predicate, clause, etc.). Grammar is not an immaterial arrangement of standards that can be neglected without results. It is the examination of principles which unite the words and go along with them to make right sentences (Weaver, McNally, \& Moerman, 2001).

\section{Syntagmatic and Paradigmatic Relations}




\section{The Effect of Syntagmatic and Paradigmatic Relationships on Learning Grammar \\ Among Iranian Pre-Intermediate EFL Learners \\ DOI: 10.30575/2017/IJLRES-2018091208}

Saussure was concerned solely with three sorts of foundational connections: that between a signifier and a connoted; those between a sign and the greater part of alternate components of its framework; and those between a sign and the components which encompass it inside a solid meaning occasion' (Silverman 1983). He accentuated that significance emerges from the contrasts between signifiers; these distinctions are of two sorts: syntagmatic (concerning situating) and paradigmatic (concerning substitution)

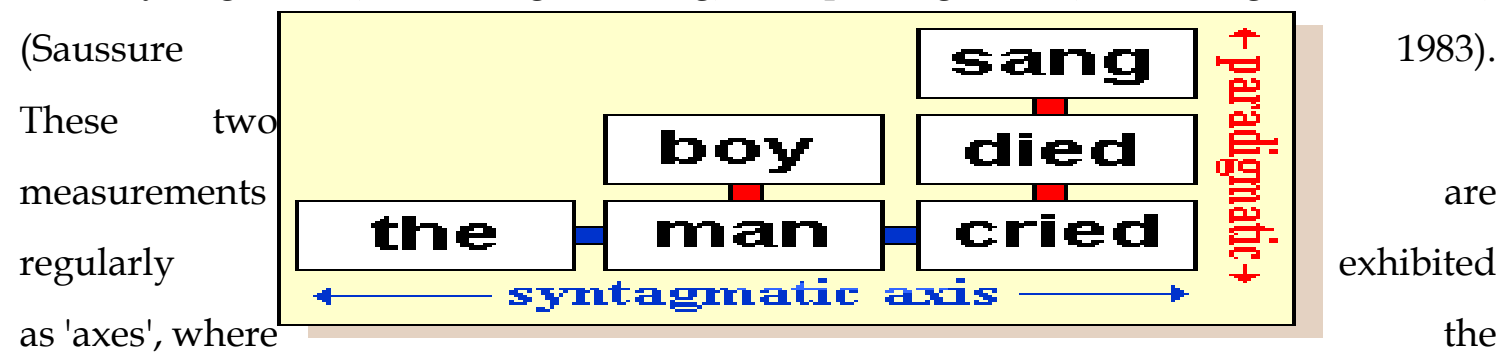
horizontal axis is the syntagmatic and the vertical axis is paradigmatic.

The plane of the syntagm is that of the blend of 'this-and-this-and-this' (as in the sentence, 'the man cried') while the plane of the worldview is that of the choice of 'thisor-this-or-this' (e.g. the substitution of the last word in a similar sentence with 'kicked the bucket' or 'sang'). While syntagmatic relations are conceivable outcomes of blend, paradigmatic relations are useful complexities - they include separation. Transiently, syntagmatic relations allude intra-literarily to different signifiers co-exhibit inside the content, while paradigmatic relations allude between literarily to signifiers which are truant from the content (Saussure 1983; Saussure 1974). The 'esteem' of a sign is controlled by the two paradigmatic and syntagmatic relations. Syntagms and ideal models give an auxiliary setting inside which signs bode well; they are the basic structures through which signs are sorted out into codes. 


\section{The Effect of Syntagmatic and Paradigmatic Relationships on Learning Grammar Among Iranian Pre-Intermediate EFL Learners DOI: $10.30575 / 2017 /$ IJLRES-2018091208}

Paradigmatic connections can work on the level of the signifier, the implied or both (Saussure 1983; Saussure 1974; Silverman 1983; Harris 1987). A paradigm is an arrangement of related signifiers or connoted which are for the most part individuals from some characterizing class, however in which each is altogether extraordinary. In normal language there are syntactic standards, for example, verbs or things. 'Paradigmatic relations are those which have a place with a similar set by prudence of a capacity they share... A sign goes into paradigmatic relations with every one of the signs which can likewise happen in a similar setting however not in the meantime' (Leymore, 1975). In a given setting, one individual from the worldview set is basically replaceable with another. 'Signs are in paradigmatic connection when the decision of one rejects the decision of another' (Silverman \& Torode 1980). The utilization of one signifier (e.g. a specific word or a piece of clothing) as opposed to another from a similar worldview set (e.g. separately, descriptive words or caps) shapes the favored significance of a content. Paradigmatic relations would thus be able to be viewed as 'contrastive'.

In summary, two types of relations exist between grammatical units: in the language framework (paradigmatic relations) and in discourse (syntagmatic relations). Paradigm and syntagm are two dimensions in semiotics that help how signs determine each other. Both ideas are utilized as a part of the printed investigation to the powerful correspondence utilizing signs. The key distinction amongst paradigm and syntagm is that paradigms are about substitution while syntagms are about the situating. The origin of syntagmatic relations and paradigmatic relations is syntagm and paradigm and refers to the connection with other syntagm.

Related to this study, Seker (2013) contemplated an outstanding short story Araby in extent of phonetic feedback as indicated by the paradigmatic and syntagmatic relations of language. Likewise, he proposed the unique circumstance and the language connection as the depth axis notwithstanding the vertical and horizontal axes. He investigated the abstract material in two guideline viewpoints in this examination, one of which is the linguistic or basic perspective, that is, the examination of the message in a morpheme, word, expression or sentence level and the other is the investigation of the content as an entire in spoken and correspondence level. The discoveries got from the investigation were severally shown and broke down on these tomahawks to talk about them as per the paradigmatic and syntagmatic relations, the previous of which is spoken 


\section{The Effect of Syntagmatic and Paradigmatic Relationships on Learning Grammar \\ Among Iranian Pre-Intermediate EFL Learners \\ DOI: $10.30575 / 2017 /$ IJLRES-2018091208}

to on vertical hub and the last of which is on the horizontal one. As indicated by the outcomes acquired in this examination, the story was found highly symbolic.

Moreover, Akbarov (2016) in an article managed the meaning of syntagma and relative syntagmas in Azerbaijani and English language. It likewise discussed the semantic and expressive highlights of syntagma as a unit of language structure. Syntagma is examined as a syntactic unit of semantics. Likewise, it extensively featured its significance. The finding demonstrated that is clarified by the scholarly exercises with indications of language (activity choice, characterization, mix, change, etc.) depend on the learning of the paradigmatic and the syntagmatic relations of components of the language framework.

\section{METHODOLOGY}

\section{Participants}

This study was conducted with the help of 70 male participants from a private language institute in Ahvaz, Iran. These students' age were ranging from 13 to 16 years old. To achieve the objectives of the present study and to evaluate the homogeneity level of the participants, all of them were given a homogeneity test (Oxford Quick Placement Test). Upon the administration of this test, 40 participants whose test scores were one standard deviation below or above the mean score were assigned to the group of study. Then they were randomly divided into two groups of control $(n=20)$ and experimental $(n=20)$. The experimental group received the treatment, which is teaching and learning grammar through using syntagmatic and paradigmatic relations. The control group received traditional teaching which was teaching grammar through instruction and drills by the teacher such as examples, drills, and repetition. The classes were conducted in the morning once a week; each session lasted about 90 minutes.

\section{Instrumentation}

\section{Oxford Quick Placement Test (OQPT)}

Initially a placement test will be taken to determine the proficiency level of learners. This will carry out through the administration of Oxford Quick Placement Test (Appendix A). The test consists of 60 items which will be answered them in 70 minutes. It comprises of two parts (Part one and Part two). There are different forms in this test 


\section{The Effect of Syntagmatic and Paradigmatic Relationships on Learning Grammar \\ Among Iranian Pre-Intermediate EFL Learners \\ DOI: 10.30575/2017/IJLRES-2018091208}

such as multiple choice, item matching, and cloze test type items in the test. In each item, there is a missing word for which there are four options. Students will find the correct item among these options. All of the 40 chosen participants for the present study were able to pass the test with a score among 28-37. The reason why the researcher of the study will decide to utilize OQPT as the students' measure of proficiency was due to the fact that the test is a standard test of proficiency, and its validity and reliability were assumed to be satisfactory.

\section{Pre-test}

Before starting the research, the participants answered a teacher-made grammar test as a pretest (Appendix B). This test included several parts: multiple-choice, fill in the blanks, substitution, and true-false. The pre-test aimed to determine the learners' knowledge of grammar before the treatment. Moreover, the pre-test was piloted on the learners with the same proficiency level to arrive at the reliability. Furthermore, the validity of the pre-test was verified by five experts who taught English for more than 5 years. The total score of this test was 40 and its reliability was calculated through Cronbach Alpha formula as $(\alpha=.865)$. The allotted time was 50 minutes and the correct answer to each item received one point. There was no penalty for false responses.

\section{Post-test}

At the end of the study, a post-test was administered to the respondents of the study. The purpose of applying such a test was to find out the effectiveness of the treatment, i.e., using syntagmatic and paradigmatic relations. The posttest was a modified version of the pre-test. The validity of the test was also checked by those teachers who validated the pre-test and the reliability was computed through the application of Cronbach Alpha formula and value of .801 was obtained.

\section{Procedure}

At first, 40 pre-intermediate EFL learners from a private language institute was selected through the administration of Oxford Quick Placement Test. They were randomly divided into two groups namely experimental $(n=20)$ and control groups $(n=20)$. Next, both 


\section{The Effect of Syntagmatic and Paradigmatic Relationships on Learning Grammar \\ Among Iranian Pre-Intermediate EFL Learners \\ DOI: 10.30575/2017/IJLRES-2018091208}

groups took a pre-test on English grammar and was checked against validity and reliability measures. Afterwards, the experimental group was taught through using syntagmatic and paradigmatic relations and the control group, on the other hand, was taught via traditional approaches. At the end of the study, a post-test was administered to the respondents of the study. The purpose of applying such a test was to find out the effectiveness of the treatment.

\section{Data Analysis}

After collecting the sufficient data through the mentioned instruments, the researcher analyzed them based on the objectives of the study to obtain the related results. Then he used SPSS software, version 22 to analyze the data. Independent and Paired Samples t-test was conducted to compare the means of the experimental group with control the group.

\section{FINDINGS}

In order to analyze data obtained from the pre and post-tests, the SPSS (22) package was utilized.

\section{Table 1.}

Descriptive Statistics

\begin{tabular}{|c|c|c|c|c|c|c|c|}
\hline & & $\mathbf{N}$ & Minimum & Maximum & Mean & $\begin{array}{c}\text { Std. } \\
\text { Deviation }\end{array}$ & $\begin{array}{c}\mathrm{N} . \\
\text { questions }\end{array}$ \\
\hline \multirow{2}{*}{ 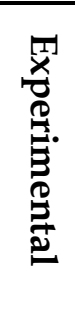 } & Pretest & 20 & 12.00 & 16.00 & 14.00 & 1.45 & 40 \\
\hline & Posttest & 20 & 30.00 & 36.00 & 32.10 & 1.65 & 40 \\
\hline \multirow{2}{*}{$\begin{array}{l}\stackrel{0}{0} \\
\stackrel{0}{0} \\
\stackrel{0}{0}\end{array}$} & Pretest & 20 & 12.00 & 16.00 & 14.10 & 1.44 & 40 \\
\hline & Posttest & 20 & 27.00 & 31.00 & 29.00 & 1.45 & 40 \\
\hline
\end{tabular}




\section{The Effect of Syntagmatic and Paradigmatic Relationships on Learning Grammar \\ Among Iranian Pre-Intermediate EFL Learners \\ DOI: 10.30575/2017/IJLRES-2018091208}

Based on the mean score presented in table 1, it shows that both groups were at the same level in pretest but in the posttest, the experimental group performed better.

\section{Table 2.}

Independent samples t-test results for participants' performance on pre-test

Levene's Test for
Equality of
Variances

\begin{tabular}{ccccc}
\hline F $\quad$ Sig. & $\mathrm{t}$ & $\mathrm{df}$ & $\begin{array}{c}\text { Sig. }(2- \\
\text { tailed) }\end{array}$ & $\begin{array}{c}\text { Mean } \\
\text { Difference }\end{array}$
\end{tabular}

\begin{tabular}{lllllll}
\hline Equal variances assumed & .002 & .967 & -.218 & 38 & .828 & -.10 \\
\hline
\end{tabular}

Table 2 shows that the significance level is higher than 0/05; this means that the difference between two groups is not significant. Thus, the two groups have been homogeneous.

\section{Pretest}

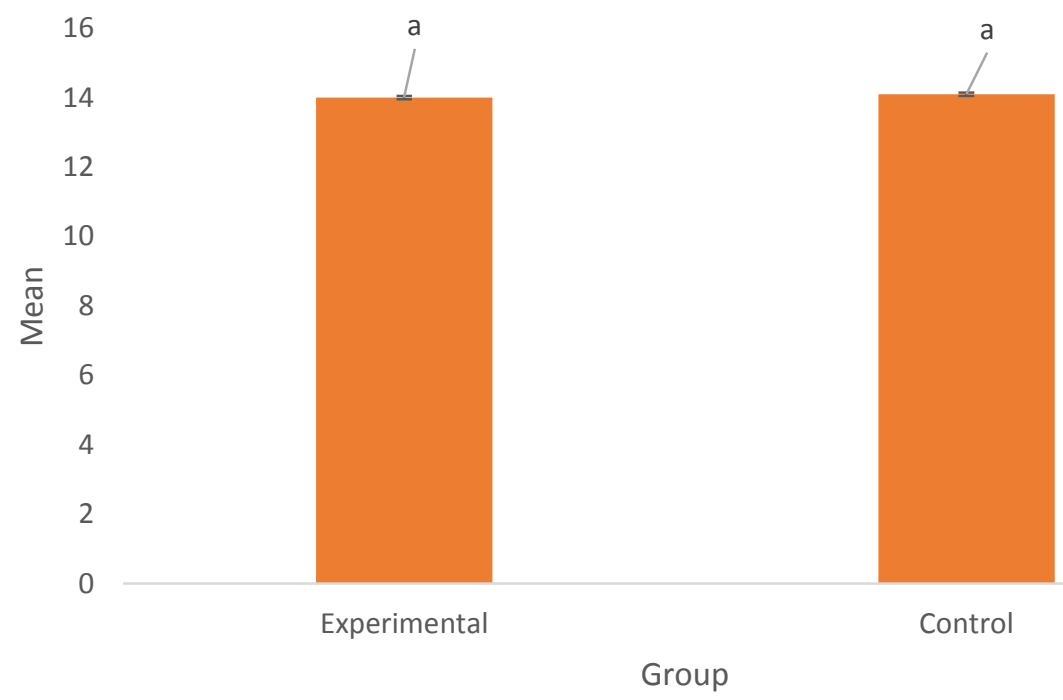

Figure 1. The mean of pre-test scores for experimental and control groups

Table 3.

Independent Samples t-test results for participants' performance on post-test 
The Effect of Syntagmatic and Paradigmatic Relationships on Learning Grammar

Among Iranian Pre-Intermediate EFL Learners

DOI: $10.30575 / 2017 /$ IJLRES-2018091208

Levene's Test for

Equality of t-test for Equality of Means

Variances

$\begin{array}{llll}\text { F } \quad \text { Sig. } & \mathrm{t}\end{array} \quad \mathrm{df} \quad \begin{array}{cc}\text { Sig. }(2- & \text { Mean } \\ \text { tailed }) & \text { Difference }\end{array}$

\begin{tabular}{lllllll}
\hline Equal variances assumed & .194 & .662 & 6.30 & 38 & .000 & 3.10
\end{tabular}

Comparing the performances of the two groups on posttest, the results of t-test suggest a $\mathrm{p}$ value of .000 which is smaller than the significance level set for the study (0.05). It means that the difference between two groups is significant. Figure 2 shows the results of Table 3 as graph.

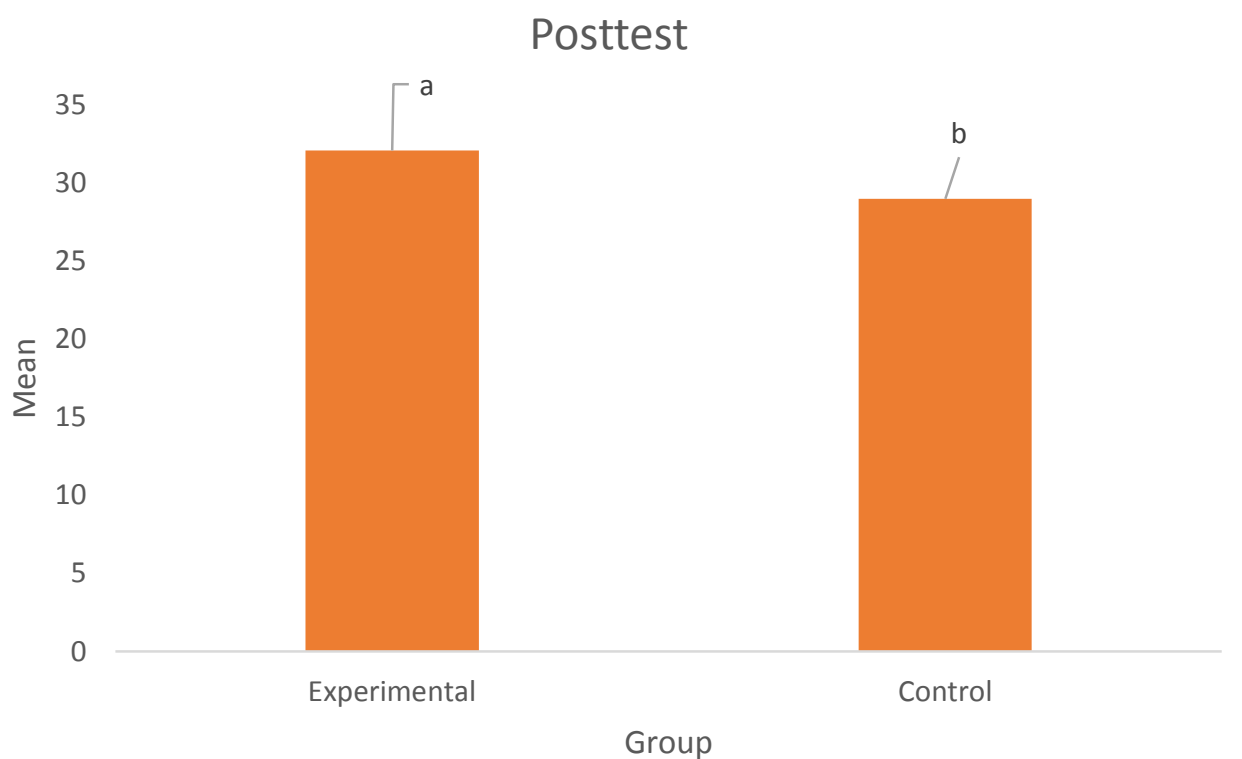

Figure 2. The mean of post-test scores for experimental and control groups

To further check the intra group changes, paired t-test was used.

Table 4.

Paired samples t-test results comparing experimental group's performance on pretest and posttest

\begin{tabular}{ccccc}
\hline & Mean & $\mathrm{t}$ & $\mathrm{df}$ & Sig. (2-tailed) \\
\hline Posttest - Pretest & 18.10 & 33.07 & 19 & .000 \\
\hline
\end{tabular}


The Effect of Syntagmatic and Paradigmatic Relationships on Learning Grammar

Among Iranian Pre-Intermediate EFL Learners

DOI: 10.30575/2017/IJLRES-2018091208

As revealed in table 4.6 , the significance level is 0.000 which is less than 0.05 . Therefore, the difference between the pre-test and post-test of the experimental group is significant.

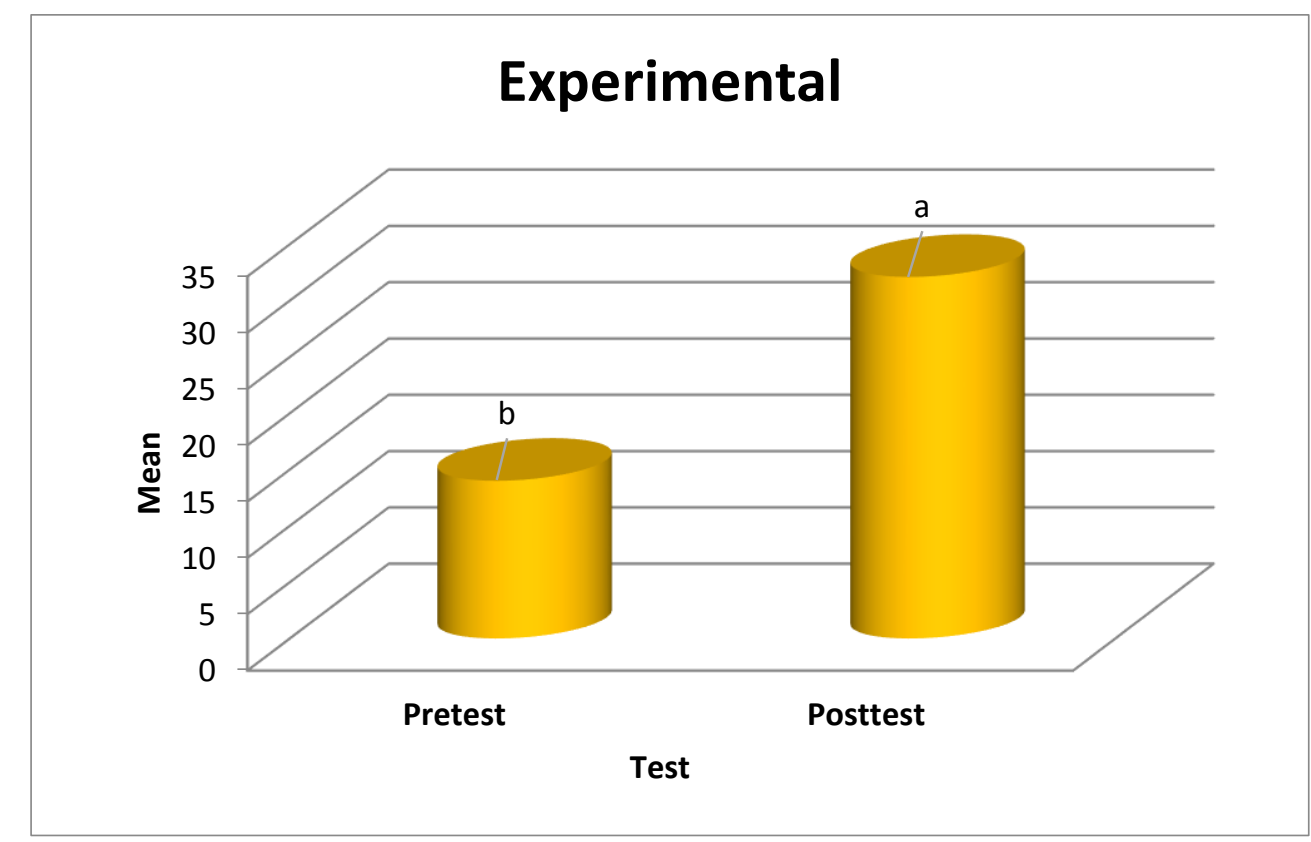

Figure 3. The mean scores of experimental group's performances on pretest and posttest

\section{Table 5.}

Paired Samples t-test results comparing control group's performances on pretest and posttest

$\begin{array}{llll}\text { Mean } & \mathrm{t} & \mathrm{df} & \text { Sig. (2-tailed) }\end{array}$

\begin{tabular}{lllll}
\hline Posttest - Pretest & 14.900 & 32.514 & 19 & .000
\end{tabular}

Based on table 5, and the significance level is 0.000 which indicates that there was a significant difference between the mean of pre-test and post-test scores in control group. Figure 4.5 shows the results of Table 5. 


\section{The Effect of Syntagmatic and Paradigmatic Relationships on Learning Grammar Among Iranian Pre-Intermediate EFL Learners DOI: 10.30575/2017/IJLRES-2018091208}

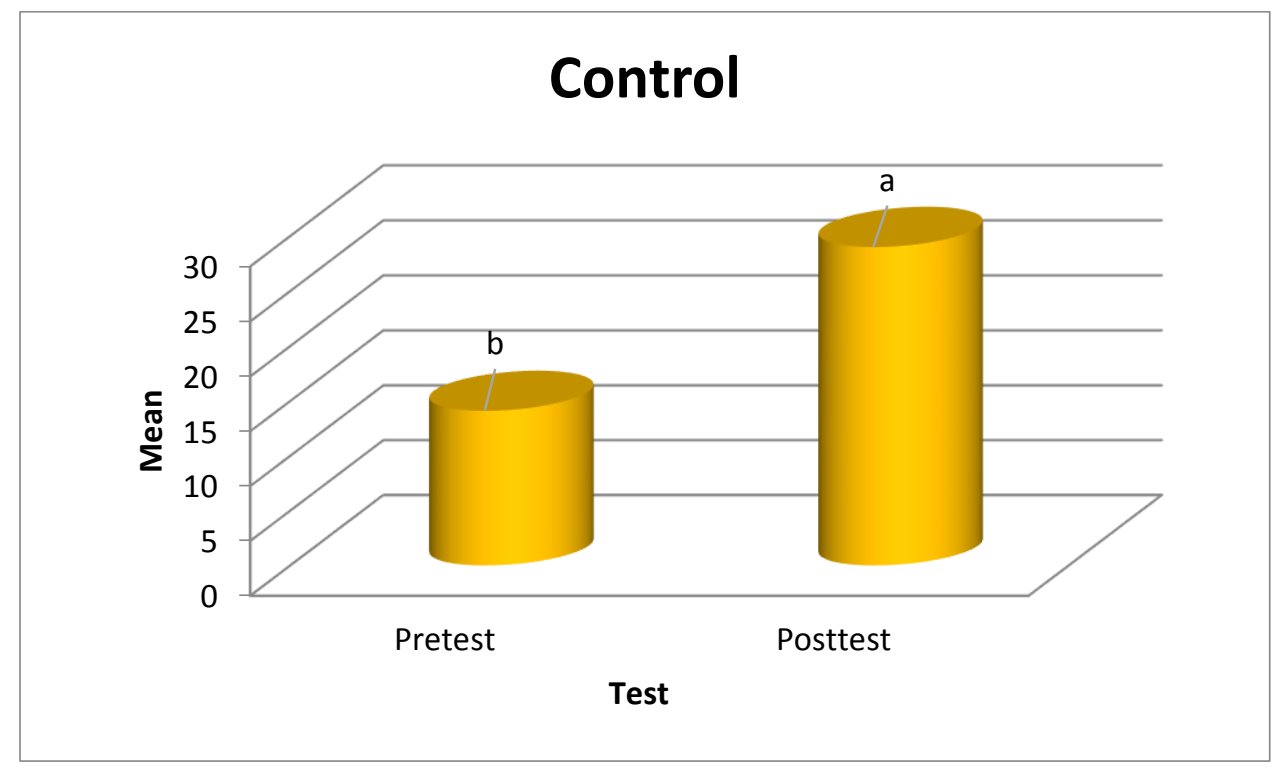

Figure 4. The mean scores of control group's performances on pretest and posttest

\section{DISCUSSION}

This section elaborates on the results and findings presented in the previous part. To discuss the results of the research, the research questions raised earlier in the study will be referred to as follows:

The results of this study are congruent to the study of Seker (2013) who researched a famous short story Araby in the extent of etymological feedback in view of the paradigmatic and syntagmatic relations of language. He believed that that in spite of the fact that the paradigmatic axis speaks to the scholarly capacity or width of language, the syntagmatic axis speaks to the mecanic one or the length. Because of the paradigmatic, syntagmatic and logical view, the lexical and auxiliary inclinations of the creator are talked about by alluding why-not-the others and the hidden or emblematic implications could be seen less demanding and more solid while considering the basic autobiographic and inter-textual discoveries in the story. With the outcomes and conclusions mentioned above, this examination presented a model for assist phonetic reactions as well as for discourse investigation.

Grammar is a segment in all language aptitudes: reading, writing, speaking, and listening. Instructors need to know tenets of punctuation (educator information) and in addition procedures that assist learners to utilize language structure adequately and easily (instructing learning). Teaching grammar incorporates not only the standards but 


\section{The Effect of Syntagmatic and Paradigmatic Relationships on Learning Grammar Among Iranian Pre-Intermediate EFL Learners DOI: $10.30575 / 2017 /$ IJLRES-2018091208}

figuring out how to control the highlights utilized by English speakers, to express certain implications and connections. Language structure (grammar) ought not to be educated independently from the four abilities (listening, speaking, reading, and writing). Teaching syntax including grammar openly implies that the educator should exhibit the language in circumstances in which it is utilized, and he/she should control the exercises that take after, enabling students to hone it in a controlled circumstance, at that point in more informative exercises, lastly in fluency exercises.

In this study, learners were encountered with grammatical points and structures through syntagmatic and paradigmatic relations to reach a better understanding of grammar. In this technique, grammatical rules and structures were presented and then followed by examples in which the rule was applied. The grammar rule was displayed and the student draws in with it through the examination and control of illustrations and multiple instances. This strategy enables the educator to manage language ridiculously, instead of anticipating them and plan for them in advance. Moreover, it encourages the learners to be more effectively engaged with the learning procedure, as opposed to being just latent beneficiaries: they are subsequently prone to be more mindful and more roused. Indeed, this strategy favors design acknowledgment and critical thinking capacities which proposes that it is especially reasonable for students who like this sort of challenge.

The use of the syntagmatic and paradigmatic relations with applying excessive examples was successful in improving the students' grammar. That finding could be inferred from the observations of the teaching and learning process. Besides, it was also supported by the result of the pre-test and post-test of the students' grammar skill. The results showed that experimental group who received grammatical points via syntagmatic and paradigmatic relations got better scores and their performance was better than the control group. It is worth noting that whereas all two experimental and control groups increased their scores from pretest to posttest, the instruction through syntagma-paradigma relations was more effective than traditional instruction.

As the researchers of this study mentioned in prior parts, syntagmatic and paradigmatic relations create the suitable situation for teaching and comprehensible and interesting information for learning grammar. In fact, the learning is active and dynamic throughout using this technique. The finding of the present study also demonstrated 


\section{The Effect of Syntagmatic and Paradigmatic Relationships on Learning Grammar \\ Among Iranian Pre-Intermediate EFL Learners \\ DOI: 10.30575/2017/IJLRES-2018091208}

that learners' exposure to syntagmatic and paradigmatic relations can lead to learning with complete awareness. Thus, learners of all levels of intelligence and aptitude can use this technique to acquire grammar.

\section{CONCLUSION}

This study started with the presumption that applying syntagmatic and paradigmatic relations could enhance the Iranian pre-intermediate EFL learners' grammar improvement. The experimental group were taught grammar, i.e. through using syntagmatic and paradigmatic relations. And the control group received usual instruction of the teacher himself. Having administered the post-test and analyzing the data through specific statistical analysis of Independent and Paired samples t-tests, the results indicated that using syntagmatic and paradigmatic relationships strategy did affect the learners' grammar learning. The students' grammar learning thanks to syntagmatic and paradigmatic relations enhanced significantly. Therefore, in answering the research questions of the study it can be maintained that the results confirmed the effectiveness of this strategy along with the case of grammar. To sum up, the findings of this study may be effective if EFL instructors attempt to help students to develop their grammar knowledge since the results of this research demonstrated that the utilization of syntagmatic and paradigmatic relations helped learners to enhance their grammar knowledge.

The results of this study can help the students to get familiar with innovative grammar teaching strategies, especially syntagmatic and paradigmatic relations and its underlying principles in order to benefit from its advantages. Moreover, The findings might be beneficial for teachers to design activities that will require them to make use of a variety of strategies and after the completion of the task they should hold a discussion session with students talking about the strategies they use, whether these strategies proved to be useful or not.

\section{BIBILIOGHAPHY}

Akbarov, H. L. (2016). Syntagmatic and paradigmatic features of relative syntagmas in Azerbaijani and English languages. European Scientific Journal (ESJ), 12(20), 214-231

Celce-Murcia, M. (1991) "language teaching approaches: an overview”. In CelceMurcia, 


\section{The Effect of Syntagmatic and Paradigmatic Relationships on Learning Grammar Among Iranian Pre-Intermediate EFL Learners DOI: $10.30575 / 2017 /$ IJLRES-2018091208}

M. (ed.) Teaching English as a second or foreign language PP. (114-117). Boston: Heinle \& Heinle publishers.

Crystal, D. (2004). Rediscover grammar (3rd ed.). Harlow, Essex: Pearson Education.

De mauro, T. (2009). A che serve la grammatica?. In Fiorentino, G. (ed.) Perché la grammatica? (pp. 28-31), Roma: Carocci editore.

Gerot, L., \& Wignell, P. (1994). Making sense of functional grammar. Sydney: Tanya Stabler.

Giunchi, P. (1990). Grammatica esplicita e grammatica implicita. In P. Giunchi (ed.), Grammatica esplicita e grammatica implicita. Bologna: Zanichelli.

Harris, R. (1987). Reading Saussure: A Critical Commentary on the 'Cours de linguistique générale'. London: Duckworth

Haruki, L (2006). The two principles of representation: paradigm and syntagm. Kansai University Institutional Library

Larsen-Freeman, D. (1991). Teaching grammar, in M. Celce-Murcia (ed.), Teaching English as a second language (pp. 279-283). Boston: Heinle \& Heinle.

Leymore, L. V. (1975). Hidden Myth: Structure and Symbolism in Advertising. - New York: Basic Books.

Myhill, D. A., \& Watson, A. (2014). The role of grammar in the writing curriculum: a review. Journal of Child Language Teaching and Therapy, 30(1), 41-62.

Pustejovsky, J. (2000). Syntagmatic Processes. In Handbook of Lexicology and Lexicography, de Gruyter.

Richards, J. C., \& Renandya, W.A. (2002). Methodology in language teaching. Cambridge: Cambridge University Press.

Richard, J. C., \& Rodgers, T. (2001). Approaches and methods in language teaching. Cambridge: Cambridge University Press.

Saussure, F. (1974). Course in General Linguistics (trans. Wade Baskin). London: Fontana/Collins

Saussure, F (1983). Course in General Linguistics [1916] (trans. Roy Harris). London: Duckworth.

Seker, E. (2013). Paradigmatic, syntagmatic and contextual relations in Araby. Uluslararası Hakemli Sosyal Bilimler E-Dergisi. 1-21

Silverman, K. (1983). The Subject of Semiotics. New York: Oxford University Press

Soleimani, H., E Khandan, M. (2013).The effect of telling short stories on learning grammar among EFL high school students in Iran. International Journal of Language Learning and Applied Linguistics World, 4(2), 110-122

Silverman, D. \& Brian, T. (1980): The Material Word: Some Theories of Language and its Limits. London: Routledge \& Kegan Paul

Swan, M. (2005). What is grammar? In Beaven, B (ed.). IATEFL. Cardiff Conference Selections: 60-61.

Ur, P. (1991). A course in language teaching. Practice and theory. Cambridge: Cambridge University Press.

Ur, P. (1991). Grammar practice activities. A practical guide for teachers. Cambridge:

Cambridge University Press.

Weaver, C., McNally, C., \& Moerman, S. (2001). To grammar or not to grammar: That is not the question! Voices from the Middle, 8(3). 17-33, Retrieved from

http://www.learner.org/workshops/middlewriting/images/pdf/W8ReadGrama.pdf 